\title{
Pengembangan Produk Olahan Gula Merah Tebu dengan Pemanfaatan Ekstrak Herbal di Desa Latellang Kabupaten Bone
}

\section{Product Development of Cane Brown Sugar Using Herbal Extract in The Latellang Village District of Bone}

\author{
${ }^{1} \mathrm{M}$ Yasser, ${ }^{1}$ Andi Muhamad Iqbal Akbar Asfar, 2Andi Muhammad Irfan \\ Taufan Asfar, ${ }^{3}$ Marlia Rianti, ${ }^{3}$ Eko Budianto \\ 1 Jurusan Teknik Kimia, Program Studi D3 Analisis Kimia, Politeknik Negeri Ujung Pandang, \\ Makassar \\ 2Jurusan MIPA, Program Studi Pendidikan Matematika, STKIP Muhammadiyah Bone, \\ Watampone \\ ${ }^{3}$ Jurusan Pendidikan Ilmu Sosial, Program Studi Pendidikan Ekonomi, STKIP \\ Muhammadiyah Bone, Watampone
}

Korespondensi: A.M.I.A. Asfar, andiqbalasfar@poliupg.ac.id

Naskah Diterima: 23 Juli 2019. Disetujui: 21 Januari 2020. Disetujui Publikasi: 23 Januari 2020

\begin{abstract}
The production of cane brown sugar is decreasing due to the low price of brown sugar form cane in the market. The low selling price of cane sugar is due to the quality and distinctive aroma of cane sugar which is less attractive to consumers. The community partnership program aims to provide solutions to partners while educating partners and citizens, especially for partner, on the benefits of cane brown sugar consumption compared to other as a form of food security as a form of persuasive methods to partners and citizens before the training takes place. This program is carried out in the form of counseling, training and mentoring. The training carried out was the manufacture of liquid sugar and instant sugar as a form of differentiation from cane brown sugar which can be of high economic value compared to selling original. The results of this program show that partners have been able to make and produce liquid sugar and instant sugar. Liquid sugar products are packaged in $250 \mathrm{ml}$ bottles, while instant sugars called recengan sugar packed in wrapping plastic weighing $25 \mathrm{~g}$, then packaged again in the form of a pouch containing 6 instant sugars. The results of the assistance show that partners have been able to make and produce liquid sugar and instant sugar and begin to expand into granulated sugar products. This differentiation product can certainly improve the price (profitable). Partner problems for the typical aroma of sugar cane can also be overcome by adding herbal extracts in the form of ginger extract and pandan leaf extract, so that the distinctive aroma of sugar cane can be disguised.

Keywords: sugar cane liquid sugar, disposable sugar, recengan sugar, sugar variations of sugar cane herbal extract.

Abstrak. Produksi gula merah tebu semakin merosot diakibatkan rendahnya harga gula merah tebu dipasaran. Rendahnya harga jual gula merah tebu disebabkan oleh kualitas dan aroma khas tebu yang kurang diminati oleh konsumen. Program kemitraan masyarakat ini dilaksanakan bertujuan untuk memberi solusi kepada mitra sekaligus mengedukasi mitra dan warga khususnya kelompok usaha gula merah tebu akan manfaat konsumsi gula merah tebu dibandingkan gula merah lainnya sebagai bentuk dari keamanan pangan melalui penyuluhan sebagai bentuk metode persuasif kepada mitra dan warga sebelum pelatihan dilaksanakan.
\end{abstract}


Program ini dilaksanakan dalam bentuk penyuluhan, pelatihan, dan pendampingan. Pelatihan yang dilakukan adalah pembuatan gula cair dan gula sekali pakai sebagai bentuk diferensiasi dari gula merah tebu yang dapat bernilai ekonomis tinggi dibandingkan hanya menjual gula merah batok. Hasil dari program ini nampak bahwa mitra telah mampu membuat dan produksi gula cair dan gula sekali pakai. Produk gula cair dikemas dalam bentuk botol $250 \mathrm{ml}$, sedangkan gula sekali pakai dengan nama produk komersilnya adalah gula recengan dikemas dalam plastik wraping dengan berat $25 \mathrm{~g}$, kemudian dikemas lagi dalam bentuk pouch yang berisi 6 buah gula sekali pakai. Hasil pendampingan menunjukkan bahwa mitra telah mampu membuat dan produksi gula cair dan gula sekali pakai serta mulai merambah ke produk gula semut. Produk diferensiasi ini tentu dapat memperbaiki harga gula merah tebu. Permasalahan mitra akan aroma khas tebu dapat pula teratasi dengan penambahan ekstrak herbal berupa ekstrak jahe dan ekstrak daun pandan, sehingga aroma khas tebu dapat tersamarkan.

Kata Kunci: gula cair tebu, gula sekali pakai, gula recengan, gula variasi tebu ekstrak herbal.

\section{Pendahuluan}

Kecamatan Patimpeng Kabupaten Bone Provinsi Sulawesi Selatan merupakan salah satu wilayah penghasil tanaman tebu dengan peningkatan produksi tahun 2015-2016 adalah 4.019.287 kg menjadi $18.867 .780 \mathrm{~kg}$ termasuk didalamnya wilayah desa Latellang (BPS Kecamatan Patimpeng, 2017). Peningkatan hasil tanaman tebu mendorong warga untuk membuat gula merah dari air nira tebu. Akan tetapi, hasil penelusuran pasar oleh tim pelaksana pada pasar tradisional di wilayah kecamatan Kahu dan Kecamatan Patimpeng bahwa harga jual gula yang dihasilkan sangat rendah yang memaksa beberapa kelompok usaha gula merah tebu untuk menghentikan produksinya. Gula merah tebu yang dihasilkan kelompok usaha gula merah tebu yaitu dalam bentuk batok. Kisaran berat untuk satu batok gula merah yaitu satu kilogram. Harga per kilogram yang dibeli secara eceran yaitu Rp.10.000, sedangkan harga jual untuk gula merah batok dari aren dihargai lebih tinggi yaitu Rp.20.000 per batok.

Faktor lain yang menjadi salah satu penyebab rendahnya minat masyarakat mengonsumsi gula merah tebu dari hasil penelusuran tim pelaksana pada pasar tradisional serta observasi pada kelompok usaha gula merah tebu yakni kualitas tebu dan aroma khas tebu pada gula merah yang dihasilkan. Keberterimaan konsumsi gula merah tebu khususnya warga desa Latellang sangat rendah sebab gula merah tebu mudah rusak serta mencair ketika disimpan lama. Begitupula pada aroma khas yang sangat spesifik pada gula merah olahan dari nira tebu yang tidak diminati oleh konsumen. Oleh karena itu, pemilik usaha gula merah tebu harus bekerja keras memasarkan gula merah produksinya di kabupaten lainnya yang membutuhkan gula merah dengan harga rendah. Permalahan lain yang muncul adalah biaya transportasi untuk pemasaran akan semakin besar, sehingga nampak kerugian dalam operasionalisasinya.

Permasalahan mitra dalam hal ini kelompok usaha gula merah tebu perlu mendapat respon dengan memberikan edukasi melalui pelatihan guna mengembangkan produk olahan gula merah dari nira tebu menjadi produk yang memiliki nilai jual serta ekonomis yakni menjadi produk gula cair dan gula sekali pakai. Produk modifikasi ini akan lebih menguntungkan secara ekonomi sebab produk yang dihasilkan akan lebih praktis serta ekonomis. Perbaikan aroma dan kualitas gula merah tebu dilakukan dengan memanfaatkan ekstrak herbal dari jahe maupun daun pandan. Penambahan ekstrak jahe maupun ekstrak daun pandan akan menyamarkan aroma khas gula merah tebu. Pemanfaatan ekstrak herbal berupa ekstrak jahe dan ekstrak pandan tidak terlepas dari minuman khas yang selama ini diminati oleh masyarakat Sulawesi Selatan. Sebagai contoh, minuman khas Sarabba yang terdiri dari bahan utama yaitu gula merah dan jahe. Agar penggunaan lebih praktis, produk yang akan dihasilkan yaitu gula merah cair ditambahkan dengan ekstrak jahe agar tidak hanya dimanfaatkan untuk membuat minuman khas Sarabba yang lebih praktis, juga dapat dimanfaatkan sebagai 
pemanis makanan dan minuman lainnya. Penambahan ekstrak pandan dilakukan sebab aroma daun pandan sangat kuat (Anggraini et al., 2011) dan memiliki aktivitas antioksidan yang baik serta sebagai tanaman yang mampu mengatasi diabetes bagi penderita diabetes (Suryani et al., 2017). Aroma daun pandan akan mampu memperbaiki aroma tebu dari gula merah tebu yang disebabkan sebab aroma daun pandan lebih kuat, disamping kandungan kimia dari daun panadan berguna bagi kesehatan manusia.

Bahan baku pembuatan gula cair dan gula sekali pakai cukup banyak tersedia sebab mayoritas petani padi mulai bergeser menjadi petani tebu. Pergeseran ini diakibatkan oleh kebutuhan pasokan tanaman tebu cukup besar untuk menunjang produksi gula pasir oleh Pabrik Gula Camming. Proses penanaman saat ini dilakukan secara mandiri yang distimulus oleh PTPN X untuk peningkatan ekonomi kerakyatan. Hasil panen tebu dijual kepada Pabrik Gula Camming dibawah naungan PTPN X, sebagian lagi masyarakat mengolahnya menjadi gula merah dalam bentuk batok. Potensi bahan baku tebu cukup besar karena luas lahan tanaman tebu di Kecamatan Patimpeng pada tahun 2016 seluas 473,47 Ha. Produksi tanaman tebu dari tahun 2015-2016 mengalami peningkatan yang cukup signifikan yaitu dari $4.019 .287 \mathrm{~kg}$ menjadi $18.867 .780 \mathrm{~kg}$ (BPS Kec. Patimpeng, 2017). Desa Latellang merupakan desa yang termasuk Swakarya, sehingga infrastruktur penunjang untuk melakukan jual beli hasil beli cukup mudah baik di Kecamatan tetangga, yaitu Kecamatan Kahu maupun akses Kecamatan Patimpeng. Jumlah penduduk Desa Latellang dari tahun 2015 ke tahun 2016 mengalami peningkatan sebesar 0,75\% yaitu semula berjumlah 1.472 jiwa menjadi 1.483 jiwa. Jumlah penduduk laki-laki pada tahun 2016 yaitu 706 jiwa dan jumlah penduduk perempuan sejumlah 777 jiwa dengan rasio 92,26 (BPS Kecamatan Patimpeng, 2017). Ketersediaan bahan baku dan sumber daya manusia tentu akan memotivasi kembali warga masyarakat khususnya kelompok usaha gula merah tebu untuk memproduksi dan mengembangkan produk yang lebih menjanjikan serta menguntungkan secara ekonomis melalui pengembangan produk berupa gula cair dan gula sekali pakai melalui pemanfaatn ekstrak herbal yakni, ekstrak jahe dan daun pandan. Disamping itu, kebutuhan akan gula rendah kalori dari tanaman serealia maupun tanaman lainnya sangat tinggi (Asfar dkk., 2018) sebagai bentuk keamanan konsumsi pangan saat ini. Hal ini, akan berdampak tumbuhnya kembali sentra produksi gula merah tebu di desa Latelang.

Tujuan dari pelaksanaan program kemitraan masyarakat ini adalah bertujuan untuk memberi solusi kepada mitra sekaligus mengedukasi mitra dan warga khususnya kelompok usaha gula merah tebu akan manfaat konsumsi gula merah tebu dibandingkan gula merah lainnya sebagai bentuk dari keamanan pangan melalui penyuluhan sebagai bentuk metode persuasif kepada mitra dan warga sebelum pelatihan dilaksanakan. Manfaat dari pelaksanaan program ini akan memberikan keterampilan dalam melakukan diferensiasi produk berupa gula cair dan gula sekali pakai serta membentuk mitra yang percaya diri akan produk yang dihasilkan, sehingga menjadi lebih produktif yang dapat menumbuhkan dan mengembangkan jiwa wirausaha yang sudah terbentuk menjadi lebih produktif secara ekonomis.

\section{Metode Pelaksanaan}

Tempat dan Waktu. Program kemitraan masyarakat ini dilaksanakan di desa Latellang Kecamatan Patimpeng Kabupaten Bone Provinsi Sulawesi Selatan. Jarak tempuh dari Makassar ke tempat pelaksanaan pengabdian yaitu $\pm 117 \mathrm{~km}$. Waktu pelaksanaan program ini yaitu dari bulan April 2019 - Juli 2019.

Khalayak Sasaran. Sasaran pelaksanaan program kemitraan ini yaitu kelompok usaha gula merah tebu yang terdiri dari 6 anggota yang berpendidikan lulusan SD 
dan lulusan SMA. Susunan keanggotaan mitra yaitu diketuai oleh Hj A. Tita (ketua) yang berpendidikan SMA, A. Ambo (SMA), A. Herianto (SMA), Akmal (SMA), A.Anwar (SD), dan Darma (SD).

Metode Pengabdian. Pelaksanaan pengabdian dilakukan dengan terlebih dahulu melaksanakan seminar singkat dalam bentuk penyuluhan. Penyuluhan ini dilakukan agar kelompok usaha gula merah tebu serta warga sekitar usaha gula merah tebu dapat memahami manfaat akan gula merah tebu dibandingkan dengan gula merah lainnya, yakni dari aren maupun kelapa. Menurut Asfar pada tahun 2019 metode ini disebut sebagai Society Parcipatory yaitu perlibatan masyarakat sebagai mitra dalam menyerap keterampilan yang diberikan dengan cara by doing (Asfar, dkk., 2019). Penyuluhan ini mampu mengedukasi kelompok usaha gula merah tebu yang merupakan mitra pengabdian dan warga masyarakat yang hadir dalam penyuluhan sekaitan dengan pemanfaatan gula merah tidak hanya sebagai gula merah dalam bentuk batok. Akan tetapi, dapat dibentuk menjadi produk modifikasi yaitu dalam bentuk gula cair maupun gula sekali pakai yang praktis. Metode pelaksanaan pengabdian terdiri dari 4 tahapan sebagai berikut:

1. Penyuluhan

Edukasi kelompok usaha gula merah tebu dilakukan melalui penyuluhan dengan memberikan pemahaman akan manfaat gula merah tebu dan modifikasi olahan gula merah tebu.

2. Pelatihan

Pelatihan dilaksanakan dengan terlebih dahulu memberikan pelatihan higienis produksi, penggunaan alat pengukuran, dan pelatihan penggunaan alat pengolahan gula merah tebu dalam memproduksi gula cair dan gula sekali pakai. Pelatihan pembuatan gula cair dan gula sekali pakai dilakukan dengan beberapa tahapan. Tahapan proses pembuatan gula cair dan gula sekali pakai adalah

a. Persiapan

b. Pemasakan

c. Pendinginan

d. Pengemasan

3. Pendampingan

Pemanfaatn hasil pelatihan melalui produksi secara mandiri oleh kelompok usaha gula merah tebu dapat dilihat dari pendampingan yang dilaksanakan. Hal-hal yang menjadi kendala akan menjadi permasalahan untuk dipecahkan agar kendala produksi dapat diminimalisir.

Indikator Keberhasilan. Luaran dari pelaksanaan program kemitraan ini sebagai indikator keberhasilan pelaksanaan program kemitraan pada kelompok usaha gula merah tebu desa Latellang adalah:

1. Mitra mampu mengetahui informasi manfaat konsumsi gula merah tebu dan memiliki keterampilan dalam melakukan diferensiasi gula merah tebu menjadi produk gula cair dan gula sekali pakai melalui modifikasi dengan memanfaatkan penambahan ekstrak herbal yaitu ekstrak jahe maupun ekstrak daun pandan dalam menyamarkan aroma tebu yang khas pada produk. Produksi minimal 13-90 botol per produksi dengan kebutuhan bahan baku minimum 500 gr dan maksimum $8 \mathrm{~kg}$ gula merah tebu.

2. Kualitas produksi gula merah tebu semakin baik dimana aroma khas tebu dapat dikurangi dengan penambahan ekstrak herbal berupa ekstrak jahe maupun daun pandan. Perbaikan aroma ditandai dengan tersamarnya aroma gula merah tebu melalui penambahan ekstrak herbal jahe dan daun pandan.

3. Mitra mampu mengoperasikan alat pengolah merah tebu menjadi gula cair dan gula sekali pakai. Kemampuan operasi maksimum 20 liter air dengan penggunaan bahan baku gula merah tebu $4 \mathrm{~kg}$ per produksi. 
Metode Evaluasi. Ketercapaian tujuan pelaksanaan program dapat diketahui dari hasil evaluasi program kemitraan pada kelompok usaha gula merah tebu di desa Latellang melalui pengamatan langsung (direct observation) oleh tim pelaksana yang mengacu pada indikator keberhasilan dan hasil yang dicapai oleh mitra. Ketercapaian tujuan pelaksanaan mengacu kepada tiga poin sebagai berikut:

1. Penyuluhan

Mitra maupun masyarakat mengetahui informasi mengenai perbandingan manfaat gula merah tebu dibandingkan dengan mengonsumsi gula pasir atau gula merah selain dari nira tebu.

2. Pelatihan

Mitra mampu menerapkan alat pengolahan gula merah tebu menjadi gula cair maupun gula sekali pakai.

3. Pendampingan

Mitra telah mampu produksi gula merah cair dan gula sekali pakai secara mandiri serta mampu membuat variasi lain dari gula merah tebu yang memiliki nilai ekonomis.

\section{Hasil dan Pembahasan}

\section{A. Penyuluhan}

Kegiatan penyuluhan dilaksanakan setelah observasi dilaksanakan sebagai bentuk sosialisasi kepada mitra dan warga desa Latellang akan pelaksanaan program kemitraan masyarakat. Pendekatan tersebut akan memberikan efek positif serta sebagai word of mouth akan antusiasme mitra dan warga yang berada disekitar lokasi pelaksanaan pengabdian program kemitaan masyarakat.

Penyuluhan dijadikan sebagai wadah bagi edukasi kepada mitra kelompok usaha gula merah tebu dan warga mengenai manfaat kesehatan akan konsumsi gula merah tebu dibandingkan gula merah lainnya, seperti aren maupun nira kelapa serta gula pasir. Perbandingan komposisi Gula Merah Aren dan Gula Merah Tebu yaitu komposisi Gula Merah Aren menurut Balai Pengkajian Teknologi Pertanian Banten pada tahun 2005 memiliki komposisi kimia yaitu kadar air $9,16 \%$, sukrosa $84,31 \%$, gula pereduksi $0,53 \%$, lemak $0,11 \%$, protein $2,28 \%$, total mineral 3,66\%, kalsium 1,35 \% dan fosfor 1,37\% (Hasanah, 2017). Gula Merah Aren mempunyai nilai kemanisan $10 \%$ lebih tinggi daripada gula pasir. Nilai kemanisan ini disebabkan oleh adanya fruktosa dalam gula merah yang memiliki nilai kemanisan lebih tinggi dibandingkan sukrosa. Gula Merah Aren juga memiliki rasa sedikit asam karena adanya kandungan asam-asam organik di dalamnya. Adanya asam-asam ini menyebabkan gula merah mempunyai aroma yang khas, sedikit asam, dan berbau karamel. Hal ini berbeda dengan Gula Merah Tebu, menurut Loto et al pada tahun 2012 memiliki kadar Sukrosa hanya 11-16\% dan kadar gula reduksi berkisar $0,4-2 \%$, kandungan mineral $0,5-1 \%$, organic non-gula 0,5-1\%, dan serat 10-16\% (Heryani, 2016).

Warga yang awalnya skeptis terhadap gula merah tebu, kemudian menyakini manfaat besar kemanan pangan termasuk mengonsumsi pemanis alami yang lebih baik bagi kesehatan selama ini, yakni mengonsumsi gula rendah kalori seperti gula merah dari tebu. Kegiatan penyuluhan juga memberikan pengetahuan baru bagi mitra dan warga akan pengolahan gula merah dari nira tebu untuk dijadikan varian produk lain yaitu gula merah cair dan gula sekali pakai serta dapat pula diolah menjadi gula semut. Ketiga produk tersebut masih belum dikenal oleh mitra dan warga. Melalui penyuluhan mitra dan warga semakin antusias untuk mengikuti pelatihan yang dilaksanakan sebagai bentuk tindak lanjut dari pelaksanaan penyuluhan pada tanggal 01 Mei 2019. Penyuluhan mengenai manfaat dan kandungan kimia serta keamanan pangan dilaksanakan oleh tim pelaksana yaitu M. Yasser dan Andi Muhamad Iqbal Akbar Asfar. Penyuluhan yang 
dilaksanakan dirangkaikan pula pelatihan pengelolaan sederhana untuk memberikan edukasi tambahan kepada mitra maupun masyarakat dalam mengelola usaha secara sederhana agar lebih menguntungkan. Narasumber pengelolaan keuangan sederhana dilakukan oleh Marlia Rianti yang memiliki kepakaran dalam manajemen dan pengelolaan keuangan.

\section{B. Pelatihan}

Pelatihan dilaksanakan dengan terlebih dahulu melakukan pengenalan dan pelatihan alat pengolahan gula cair dan gula sekali pakai. Untuk mengedukasi mitra dalam higienis dalam produksi, pelatihan dilaksanakan pula mengenai pemakaian kaos tangan, masker, dan penutup kepala dalam produksi gula cair dan gula sekali pakai nantinya. Pelatihan penggunaan alat ukur timbangan dan volume juga dilaksanakan agar pengetahuan mitra akan pengukuran berat dan volume bahan serta produk dapat lebih akurat.

Pelatihan pengolahan gula merah tebu menjadi gula recengan dilaksanakan dengan menggunakan alat pengolahan gula merah tebu dengan mengombinasikan dengan ekstrak herbal yaitu ekstrak jahe dan ekstrak daun pandan. Adapun pelaksanaan pelatihan pembuatan gula cair dan gula sekali pakai sebagai berikut:

a. Persiapan

Persiapan dilakukan dengan menyiapkan bahan dan alat yang akan digunakan termasuk ekstrak jahe maupun pandan yang akan digunakan. Persiapan ekstrak jahe dan daun pandan dengan cara memarut kemudian di peras. Ekstrak disiapkan untuk jahe sebanyak $160 \mathrm{ml}(80 \mathrm{ml}$ untuk masing-masing gula cair dan gula sekali pakai) dan ekstrak pandan sebanyak $500 \mathrm{ml}(250 \mathrm{ml}$ untuk masing-masing gula cair dan gula sekali pakai).

b. Pemasakan

Pemasakan dilakukan dengan menggunakan alat pengolahan gula cair dan gula sekali pakai dengan suhu pemasakan $110^{\circ} \mathrm{C}-120^{\circ} \mathrm{C}$. Gula merah tebu dalam bentuk batok sebanyak 500 gram dipecah kemudian ditambahkan $600 \mathrm{ml}$ air ke dalam wajan pemasakan kemudian ditambahkan $80 \mathrm{ml}$ esktrak jahe kemudian dimasak dengan api sedang hingga mendidih dan dilanjutkan api kecil hingga sedikit mengental. Waktu pemsakan hingga 20 menit dapat dilihat pada Gambar 1. Perlakukan untuk gula cair dengan ekstrak daun pandan sama dengan pembuatan gula cair, tetapi ekstrak daun pandan yang ditambahkan adalah 250 $\mathrm{ml}$ ekstrak dan $350 \mathrm{ml}$ air.

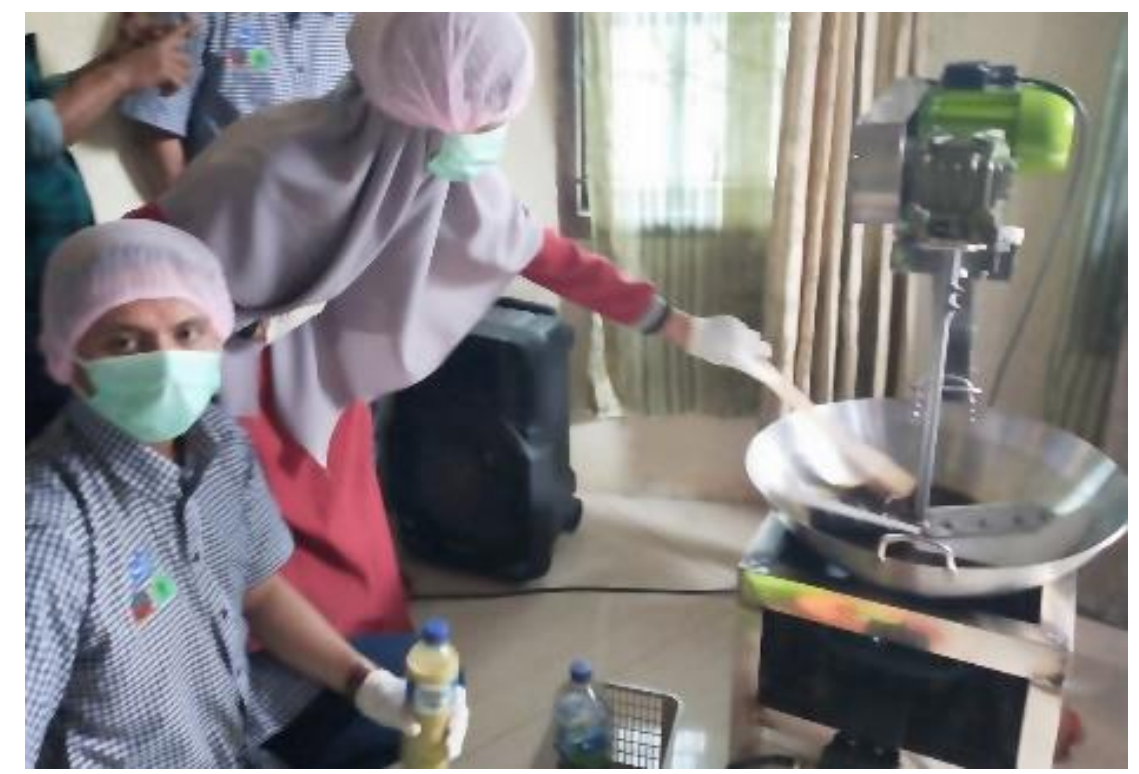

Gambar 1. Proses pemasakan gula cair dan gula sekali pakai 
Pembuatan gula sekali pakai juga menggunakan alat pengolahan gula merah tebu dengan menggunakan bahan baku gula merah tebu sebanyak 500 gram dengan menambahkan esktrak jahe dan air masing-masing $80 \mathrm{ml}$ dan $420 \mathrm{ml}$. pemasakan dilakukan dengan suhu $110^{\circ} \mathrm{C}-120^{\circ} \mathrm{C}$ selama 30 menit hingga larutan gula mengental. Variasi dengan ekstrak daun pandan sama dengan pemasakan menggunakan ekstrak jahe, tetapi penambahan air dan ekstrak daun pandan adalah masing-masing $250 \mathrm{ml}$ dan $250 \mathrm{ml}$.

c. Pendinginan

Proses pendinginan pada Gambar 2 untuk gula cair dilakukan hingga larutan gula cair dingin baik untuk aroma ekstrak jahe maupun daun pandan. Akan tetapi, untuk gula sekali pakai memiliki perlakuan yang berbeda, yaitu harus langsung dikemas setelah didinginkan selama 5 menit sebab jika terlambat, maka adonan akan semakin keras serta agak sulit untuk dicetak ke dalam wadah pencetak gula sekali pakai (ketebalan $1 \mathrm{~cm}$ dan diameter 2,5 cm). Setelah dimasukkan ke dalam pencetakan, gula sekali pakai didinginkan kemudian siap untuk dikemas.

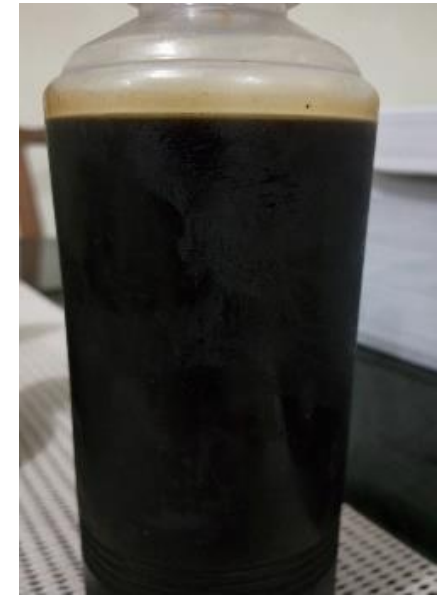

Gambar 2. Proses pendinginan gula cair dan pencetakan gula sekali pakai (recengan)

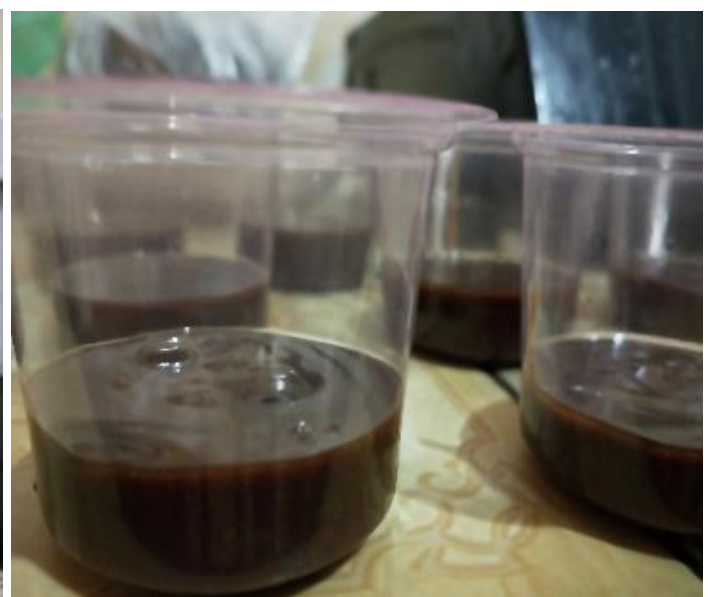

\section{d. Pengemasan}

Pengemasan untuk gula cair menggunakan botol kaca $250 \mathrm{ml}$ kemudian diberikan label sesuai varian aroma baik ekstrak jahe maupun ekstrak pandan. Untuk gula recengan dikemas dengan menggunakan plastik wraping, label kemasan diberikan sesuai varian aroma jahe maupun daun pandan dengan berat gula sekali pakai 25 gram, kemudian di kemas ke dalam pouch yang berisi enam biji gula sekali pakai dan diberikan label kemasan sebagai gula recengan untuk komersialisi atau gula sekali pakai sesuai varian rasa dapat dilihat pada Gambar 3.

\section{Pendampingan}

Pendampingan dilaksanakan untuk menemukenali permasalahan mitra setelah pelatihan dilaksanakan (Gambar 4). Pendampingan dimaksudkan pula untuk mengevaluasi kemampuan mitra dalam membuat gula cair dan gula sekali pakai sekaligus kemampuan mitra akan mengembangkan produk yang dihasilkan dari olahan gula merah tebu. Dari hasil pendampingan, mitra telah mampu membuat gula sekali pakai dan mampu memanfaatkan alat untuk mencoba membuat gula semut dari gula merah tebu dengan penambahan ekstrak pandan. Ekstrak jahe tidak dikembangkan untuk menjadi gula semut sebab teksturnya lebih liat dan kurang mampu mengeras. Penambahan ekstrak pandan juga menjadi solusi terhadap mitra akan kualitas gula merah tebu yang sedikit mudah menyerap air menjadi lebih keras seperti gula aren. Pada gula merah baik aren dan tebu, 
kadar air akan mempengaruhi kekerasan gula merah yang dihasilkan. Kadar air yang terlalu tinggi akan menyebabkan gula merah menjadi lembek dan cepat mengalami kerusakan selama penyimpanan. Kadar air terlalu tinggi akan menjadi masalah bagi produksi Gula Merah Tebu (Widiantara, dkk., 2018).

Keuntungan lainnya dengan penambahan ekstrak pandan, yakni aroma khas tebu tersamarkan, begitupula pada penambahan ekstrak jahe. Pembuatan gula cair dan gula sekali pakai dapat dikatakan berhasil mengatasi permasalahan mitra akan kualitas dan diferensiasi produk dari gula merah tebu batok menjadi gula cair dan gula sekali pakai dengan penambahan ekstrak herbal jahe dan daun pandan.

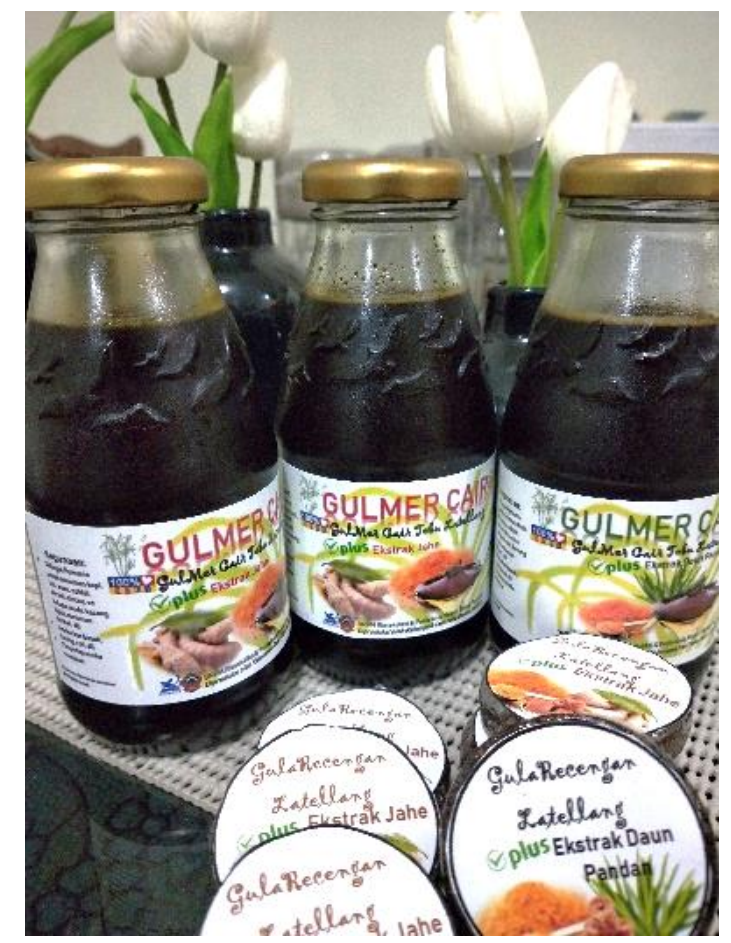

Gambar 3. Produk gula cair dan gula sekali pakai (recengan)

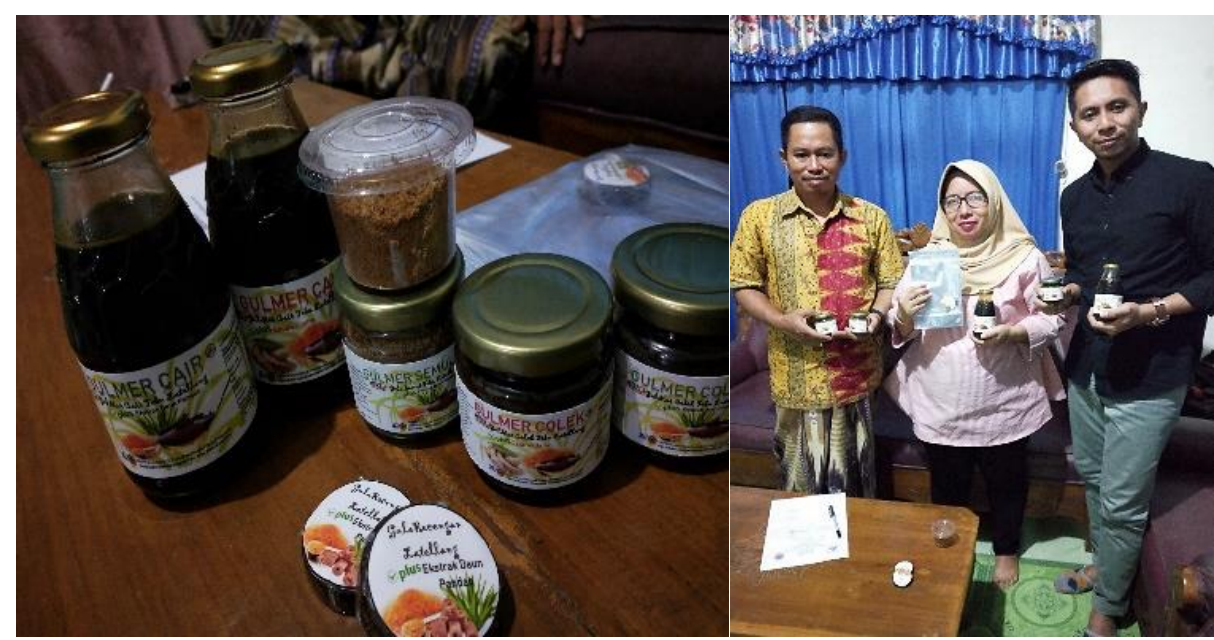

Gambar 4. Pendampingan Mitra

\section{Keberhasilan Kegiatan}

Keberhasilan pelaksanaan program kemitraan masyarakat ini mampu mengedukasi mitra yakni kelompok usaha gula merah tebu akan informasi mengenai manfaat gula merah tebu dibandingkan dengan mengonsumsi gula pasir 
maupun gula merah lainnya selain tebu. Program ini juga mampu memberikan pengetahuan kepada mitra akan diferensiasi produk gula merah batok tebu menjadi gula cair dan gula sekali pakai yang lebih praktis dengan memanfaatkan alat pengolah gula merah tebu. Kualitas gula cair dan gula sekali pakai juga semakin baik, dimana aroma khas tebu dapat disamarkan dengan penambahan ekstrak herbal berupa ekstrak jahe dan ekstrak daun pandan. Pemenuhan bahan baku tanaman jahe dan daun pandan cukup melimpah di desa Latellang. Sedangkan gula merah tebu dipasok dari hasil produksi gula merah batok. Ratarata produksi gula cair adalah 60 botol per bulan serta gula sekali pakai yaitu 180 biji dengan rata-rata bahan baku yang dugunakan adalah 2-2,5 kg gula merah tebu batok. Produksi yang masih rendah sebab masih sangat bergantung dengan permintaan konsumen serta produk gula merah cair dan gula sekali pakai masih baru di sekitar wilayah kecamatan Patimpeng. Akan tetapi, pemasaran telah menggunakan media online. Proses pemesanan melalui dua bentuk yaitu online dan offline. Online melalui whatsapp dan offline mealui datang langsung ke tempat mitra. Keberhasilan yang dirasakan mitra bahwa harga gula merah batok dapat ditingkatkan melalui diferensiasi produk dalam bentuk gula cair dan gula sekali pakai sebab hanya 500 gram gula merah tebu batok dapat menghasilkan 13 botol gula cair $(250 \mathrm{ml})$ dan 30 gula sekali pakai. Harga gula merah semula adalah Rp.10.000 per kg, dengan hanya menjual 1 botol dengan harga Rp.10.000 mampu memberikan keuntungan maksimal dibandingkan mitra hanya menjual gula merah batok saja.

\section{Kesimpulan}

Mitra terampil dalam melakukan diferensiasi gula merah tebu menjadi produk gula cair dan gula sekali pakai melalui modifikasi dengan memanfaatkan penambahan ekstrak herbal yaitu ekstrak jahe maupun ekstrak daun pandan dalam menyamarkan aroma tebu yang khas pada produk. Mitra mampu mengoperasikan alat pengolah merah tebu menjadi gula cair dan gula sekali pakai. Program Kemitraan Masyarakat ini telah berhasil menyelesaikan permasalahan mitra akan harga dan aroma gula merah tebu serta mitra mampu menghasilkan produk yang memiliki nilai ekonomis tinggi.

\section{Ucapan Terima Kasih}

Penulis menyampaikan terima kasih kepada DRPM Kemenristekdikti, Mitra Kelompok Usaha Gula Merah Tebu desa Latellang, Pemerintah Kecamatan Patimpeng Kabupaten Bone, STKIP Muhammadiyah Bone, Pimpinan PNUP, P3M PNUP, Dosen dan Staf, PLP (teknisi dan analis) Jurusan Teknik Kimia Politeknik Negeri Ujung Pandang atas bantuannya selama PKM ini dilaksanakan.

\section{Referensi}

Anggraini, S.D., Wijana, S., \& Mulyadi, A.F. (2011). Pengaruh Penambahan Konsentrasi Daun Pandan Wangi (Pandanus Amarillifolius Roxb.) dan Lama Pemanasannya Pada Pembuatan Sirup Gula Kelapa Aroma Pandan. https://www.researchgate.net/publication/291347442 (Diakses pada 17 Maret 2019).

Asfar, A.M.I.A., Arifuddin, W., \& Rahman, A. (2019). Pengolahan Kayu Sepang Di Desa Biru Kecamatan Kahu Kabupaten Bone. Jurnal Panrita Abdi, 3(2), 97 104.

Asfar, A.M.I.A. (2018). Characterization of Saccharide Sugar in Corn Seed (Zea Mays Saccharata) By Using Gas Chromatography Mass Spectrometry Method. JBAT, 7(1), 70-76. 
Badan Pusat Statistik Kabupaten Bone. (2017). Kecamatan Patimpeng. Katalog: 1102001.7311.020. Watampone: BPS Kabupaten Bone.

Hasanah, S.Z. (2017). Pengaruh Perbandingan Gula Merah Cair dan Nira Terhadap Karakteristik Gula Semut (Palm Sugar). Jurusan Teknologi Pangan, Fakultas Teknik, Universitas Pasundan Bandung, hal: 2.

Heryani, H. (2016). Keutamaan Gula Aren \& Strategi Pengembangan Produk. Banjarmasin: Lambung Mangkurat University Press, hal: 31.

Suryani, C.L., Tamaroh, S., Ardiyan, A., \& Setyowati, A. (2017). Aktivitas Antioksidan Ekstrak Etanol Daun Pandan (Pandanus amaryllifolius) dan Fraksi-Fraksinya. AGRITECH, 37(3), 271-279.

Widiantara, T., Hervelly, \& Nur'Afiah. D. (2018). Pengaruh Perbandingan Gula Merah Dengan Sukrosa dan perbandingan Tepung Jagung, Ubi Jalar Dengan Kacang Hijau Terhadap Karakteristik Jenang. Pasundan Food Technology Journal, 5(1), 1-9.

Penulis:

M.Yasser, Jurusan Teknik Kimia, Program Studi D3 Analisis Kimia, Politeknik Negeri Ujung Pandang, Makassar. E-mail: andiiqbalasfar@poliupg.ac.id

Andi Muhamad Iqbal Akbar Asfar, Jurusan Teknik Kimia, Program Studi D3 Teknik Kimia, Politeknik Negeri Ujung Pandang, Makassar. E-mail: andiiqbalasfar@poliupg.ac.id

Andi Muhammad Irfan Taufan Asfar, Jurusan Pendidikan Matematika, Program Studi Matematika dan Ilmu Pengetahuan Alam, STKIP Muhammadiyah Bone, Watampone. E-mail: tauvanlewis00@gmail.com

Marlia Rianti, Jurusan Pendidikan Ekonomi, Program Studi Pendidikan Ilmu Sosial, STKIP Muhammadiyah Bone, Watampone, E-mail: marliarianti@gmail.com

Eko Budianto, Jurusan Pendidikan Ekonomi, Program Studi Pendidikan Ilmu Sosial, STKIP Muhammadiyah Bone, Watampone, E-mail: ekobudianto23@gmail.com

Bagaimana men-sitasi artikel ini:

Yasser, M., Asfar, A.M.I.A., Asfar, A.M.I.T., Rianti, M., \& Budianto, E. (2020). Pengembangan Produk Olahan Gula Merah Tebu dengan Pemanfaatan Ekstrak Herbal di Desa Latellang Kabupaten Bone. Jurnal Panrita Abdi, 4(1), 42 - 51. 